\title{
Malonate as a Precursor in the Biosynthesis of Aflatoxins
}

\author{
By S. R. GUPTA, H. R. PRASANNA, L. VISWANATHAN* AND \\ T. A. VENKITASUBRAMANIAN \\ Department of Biochemistry, Vallabhbhai Patel Chest Institute, \\ University of Delhi, Delhi-7, India
}

(Received 5 November I974; revised 16 December 1974)

\begin{abstract}
SUMMAR Y
Incorporation of $\left[{ }^{1-14} \mathrm{C}\right]$ acetate and $\left[2-{ }^{14} \mathrm{C}\right]$ malonate into aflatoxins by resting mycelia of Aspergillus parasiticus resuspended in different buffers was studied. A decrease in pH from $5 \cdot 8$ to $2 \cdot 8$, as well as addition of EDTA, markedly stimulated the incorporation of malonate but the effect on acetate incorporation was less pronounced. Mycelia took up comparatively more acetate than malonate, but more malonate $(4.3 \%)$ entering mycelia was incorporated into aflatoxins than was acetate $(\mathrm{I} \cdot 6 \%)$. Furthermore, the addition of unlabelled acetate reduced the incorporation of label from $\left[\mathrm{I}^{14} \mathrm{C}\right]$ acetate by $75 \%$ but from $\left[2-{ }^{14} \mathrm{C}\right.$ )malonate by only $25 \%$. These results suggest that malonate is an intermediate in aflatoxin synthesis and that it can be incorporated without prior conversion to acetate.
\end{abstract}

\section{INTRODUCTION}

Although there are a number of reports on the biosynthesis of aflatoxins, information about the metabolic routes involved is scanty (Adye \& Mateles, 1964; Biollaz, Büchi \& Milne, I968, I970; Detroy \& Hesseltine, 1969; Hsieh \& Mateles, I970, I97I ; Lin et al. 1973). Aflatoxin is believed to be synthesized by the polyacetate pathway (Biollaz et al. 1968). The similarity between polyacetate and fatty acid pathways prompted a study of the role of malonate in polyacetate biosynthesis. Malonate was shown to be a precursor for orsellinic acid and 6-methylsalicylic acid (Bentley \& Keil, I96I; Bu'Lock \& Smalley, I96I ; Birch, Cassera \& Rickards, 196I). The present study was undertaken to ascertain the role of malonate in the synthesis of aflatoxins by comparing the incorporation of $\left[2-{ }^{14} \mathrm{C}\right]$ malonate with that of $\left[\mathrm{I}-{ }^{14} \mathrm{C}\right]$ acetate.

\section{METHODS}

Aspergillus parasiticus NRRL3240 was obtained from the Northern Regional Research Laboratory, Peoria, Illinois, U.S.A., and maintained as a soil culture. $\left[\mathrm{I}^{-11} \mathrm{C}\right]$ acetate and $\left[2^{14} \mathrm{C}\right]$ malonate were obtained from Bhabha Atomic Research Centre, Trombay, Bombay, India. Spores, from 5- to 6-day-old cultures on $50 \mathrm{ml}$ of glucose-peptone-agar medium, were suspended in sterile double-distilled water and transferred to $100 \mathrm{ml}$ of sterile medium contained in $500 \mathrm{ml}$ Erlenmeyer flasks. The synthetic medium used had the following composition: $85 \mathrm{~g}$ sucrose, Io $\mathrm{g}$ asparagine, $3.5 \mathrm{~g}\left(\mathrm{NH}_{4}\right)_{2} \mathrm{SO}_{4}$, $10 \mathrm{~g} \mathrm{KH}_{2} \mathrm{PO}_{4}, 2 \mathrm{~g} \mathrm{MgSO}_{4} \cdot 7 \mathrm{H}_{2} \mathrm{O}$, $75 \mathrm{mg} \mathrm{CaCl} .2 \mathrm{H}_{2} \mathrm{O}$, $10 \mathrm{mg} \mathrm{ZnSO}_{4} \cdot 7 \mathrm{H}_{2} \mathrm{O}, 5 \mathrm{mg} \mathrm{MnCl}_{2} .4 \mathrm{H}_{2} \mathrm{O}, 2 \mathrm{mg}$ ammonium molybdate. $4 \mathrm{H}_{2} \mathrm{O}, 2 \mathrm{mg} \mathrm{Na}_{2} \mathrm{~B}_{4} \mathrm{O}_{7}$, and $2 \mathrm{mg} \mathrm{FeSO}_{4} \cdot 7 \mathrm{H}_{2} \mathrm{O}$, made to I 1 with double-distilled water. The $\mathrm{pH}$ of the medium was adjusted to $4 \cdot 5$. The fungus was grown at $26 \pm \mathrm{I}{ }^{\circ} \mathrm{C}$, as stationary cultures, for 4 days. Mycelia were separated and washed with double-distilled water and known amounts resuspended in $250 \mathrm{ml}$ Erlenmeyer flasks containing $50 \mathrm{ml}$ of sterile

\footnotetext{
* Present address: National Sugar Institute, Kanpur-I 7, India.
} 
Table r. Incorporation of $\left[\mathrm{I}-{ }^{14} C\right]$ acetate and $\left[2-{ }^{14} C\right]$ malonate into aflatoxins $B$ and $G$

\begin{tabular}{|c|c|c|c|}
\hline \multirow[b]{2}{*}{ Resuspension medium } & \multirow[b]{2}{*}{ Compound added } & \multicolumn{2}{|c|}{$\begin{array}{l}\text { Specific activity of } \\
\text { aflatoxins (c.p.m./mg) }\end{array}$} \\
\hline & & B & $\mathrm{G}$ \\
\hline $\begin{array}{l}0.02 \text { M-Phosphate buffer } \\
\text { pH } 5.8\end{array}$ & $\begin{array}{l}{\left[\mathrm{I}-{ }^{14} \mathrm{C}\right] \text { acetate }} \\
{\left[\mathrm{I}-{ }^{14} \mathrm{C}\right] \text { acetate }+40 \mathrm{~mm}-\mathrm{EDTA}} \\
{\left[\mathrm{I}-{ }^{14} \mathrm{C}\right] \text { acetate }+40 \mathrm{mg} \text { unlabelled acetate }} \\
{\left[2-{ }^{14} \mathrm{C}\right] \text { malonate }} \\
{\left[2-{ }^{14} \mathrm{C}\right] \text { malonate }+40 \mathrm{~mm} \text {-EDTA }} \\
{\left[2-{ }^{14} \mathrm{C}\right] \text { malonate }+40 \mathrm{mg} \text { unlabelled }} \\
\text { acetate }\end{array}$ & $\begin{array}{r}34 \mathrm{I} 08 \\
45297 \\
802 \mathrm{I} \\
3342 \\
\mathrm{I} 2 \mathrm{II} 2 \\
23 \mathrm{I} 3\end{array}$ & $\begin{array}{r}40237 \\
62318 \\
10156 \\
6640 \\
20019 \\
5128\end{array}$ \\
\hline $\begin{array}{l}0.02 \mathrm{M} \text {-Citrate-phosphate } \\
\text { buffer } \mathrm{pH} 2.8\end{array}$ & $\begin{array}{l}{\left[\mathrm{I}^{-14} \mathrm{C}\right] \text { acetate }} \\
{\left[\mathrm{I}-{ }^{-14} \mathrm{C}\right] \text { acetate }+ \text { Io } \mathrm{mM}-\mathrm{EDTA}} \\
{\left[2-{ }^{-14} \mathrm{C}\right] \text { malonate }} \\
{\left[2-{ }^{-14} \mathrm{C}\right] \text { malonate }+ \text { Io } \mathrm{mM}-\mathrm{EDTA}}\end{array}$ & $\begin{array}{r}25738 \\
38131 \\
9828 \\
20012\end{array}$ & $\begin{array}{l}31219 \\
72254 \\
15322 \\
36134\end{array}$ \\
\hline $\begin{array}{l}0.02 \mathrm{M}-\mathrm{KCl}-\mathrm{HCl} \text { buffer } \\
\mathrm{pH} 2 \cdot 0\end{array}$ & $\begin{array}{l}{\left[\mathrm{I}^{-14} \mathrm{C}\right] \text { acetate }+ \text { Io mM-EDTA }} \\
{\left[{ }^{2-14} \mathrm{C}\right] \text { malonate }+ \text { Io mM-EDTA }}\end{array}$ & $\begin{array}{l}38233 \\
15237\end{array}$ & $\begin{array}{l}61040 \\
24158\end{array}$ \\
\hline
\end{tabular}

$0.02 \mathrm{M}$-phosphate buffer $\mathrm{pH}_{5} \cdot 8$, citrate-phosphate buffer $\mathrm{pH} 2 \cdot 8$, or $\mathrm{KCl}-\mathrm{HCl}$ buffer $\mathrm{pH} 2 \cdot 0$, and $5 \mu \mathrm{Ci}\left[\mathrm{I}-{ }^{14} \mathrm{C}\right]$ acetate or $\left[2-{ }^{14} \mathrm{C}\right]$ malonate (specific activity $0.423 \mathrm{mCi} / \mathrm{mm}$ ) were added. In some cases, EDTA, unlabelled acetate or avidin was also added to the resuspension buffer.

After incubating for $2 \mathrm{~h}$, aflatoxins were extracted from the mycelium with chloroform and separated by thin-layer chromatography on silica gel $G$, with an initial run in ether and then in $2 \%$ methanol in chloroform. Aflatoxins were eluted with methanol and estimated by spectrophotometry (Nabney \& Nesbitt, 1965). Thin-layer chromatography for neutral lipids was done as described by Misra (1968). Radioactivity incorporated into aflatoxins, triglycerides, free fatty acids, and free and esterified sterols was determined on a Beckman LS-233 liquid scintillation counter. Radiopurity of the toxins was checked by the method of Gupta et al. (1974).

Incorporation of $\left[\mathrm{I}^{14} \mathrm{C}\right]$ acetate and $\left[2^{-14} \mathrm{C}\right]$ malonate into mycelium and respiratory $\mathrm{CO}_{2}$. About $200 \mathrm{mg}$ of 4 -day-old mycelium were divided into small portions and transferred to a Warburg flask containing $2.8 \mathrm{ml}$ of $0.02 \mathrm{M}$-citrate-phosphate buffer $\mathrm{pH} 2.8$ in the main compartment and $0.2 \mathrm{ml}$ of $20 \%$ potassium hydroxide in the centre well. [ ${ }^{1-}{ }^{14} \mathrm{C}$ ]acetate or $\left[2-{ }^{14} \mathrm{C}\right]$ malonate $(0.5 \mu \mathrm{Ci})$ was added from the side arm and the reaction allowed to proceed for $2 \mathrm{~h}$ at $27^{\circ} \mathrm{C}$. The trapped $\mathrm{CO}_{2}$ was precipitated as barium carbonate and collected on filter-paper discs. The mycelial portions were extracted first with chloroform and then with chloroform-methanol $(2: \mathrm{I}, \mathrm{v} / \mathrm{v})$, dried at $60^{\circ} \mathrm{C}$, ground, and transferred quantitatively into scintillation vials. Radioactivity was measured in the original buffer, aflatoxins, ground mycelium, trapped $\mathrm{CO}_{2}$ and the mycelial extracts. Data presented are the averages of three separate experiments.

\section{RESULTS AND DISCUSSION}

Experiments in this laboratory have shown that there was little difference between the pattern of incorporation obtained with $\left[\mathrm{I}^{-14} \mathrm{C}\right]$ acetate and $\left[2-{ }^{14} \mathrm{C}\right]$ acetate. Therefore, only $\left[\mathrm{I}^{-14} \mathrm{C}\right]$ acetate was used to compare the incorporation of acetate with that of labelled malonate.

A decrease in the $\mathrm{pH}$ of the resuspension medium from 5.8 to 2.8 markedly stimulated incorporation of malonate into aflatoxins (Table I). This was probably due to preferential uptake of the less ionized form of malonic acid (Webb, I966). Incorporation of $\left[\mathrm{I}^{14} \mathrm{C}\right]$ acetate and $\left[2-{ }^{14} \mathrm{C}\right]$ malonate was also studied in the presence of EDTA, because of the ability of 
Table 2. Incorporation of $\left[\mathrm{I}^{-14} \mathrm{C}\right]$ acetate and $\left[2-{ }^{14} \mathrm{C}\right]$ malonate into aflatoxins and neutral lipids

\begin{tabular}{|c|c|c|c|c|c|c|}
\hline \multirow[b]{2}{*}{$\begin{array}{l}\text { Resuspension } \\
\text { medium }\end{array}$} & \multirow[b]{2}{*}{$\begin{array}{l}\text { Compound } \\
\text { added }\end{array}$} & \multirow{2}{*}{$\begin{array}{l}\text { Radioactivity } \\
\text { incorporated } \\
\text { into mycelial } \\
\text { aflatoxins } \\
\text { (c.p.m.) }\end{array}$} & \multicolumn{4}{|c|}{$\begin{array}{c}\text { Radioactivity incorporated into mycelial } \\
\text { neutral lipids (c.p.m.) }\end{array}$} \\
\hline & & & $\begin{array}{l}\text { Tri- } \\
\text { glycerides }\end{array}$ & $\begin{array}{l}\text { Free fatty } \\
\text { acids }\end{array}$ & $\begin{array}{l}\text { Esterified } \\
\text { sterols }\end{array}$ & $\begin{array}{l}\text { Free } \\
\text { sterols }\end{array}$ \\
\hline $\begin{array}{l}0.02 \mathrm{M}-\mathrm{Phosphate} \\
\text { buffer } \mathrm{pH} 5 \cdot 8^{*}\end{array}$ & $\begin{array}{l}{\left[\mathrm{I}-{ }^{14} \mathrm{C}\right] \text { acetate }} \\
{\left[2-{ }^{14} \mathrm{C}\right] \text { malonate }}\end{array}$ & $\begin{array}{r}179400 \\
20440\end{array}$ & $\begin{array}{r}545420 \\
42640\end{array}$ & $\begin{array}{r}424380 \\
36960\end{array}$ & $\begin{array}{r}13420 \\
1820\end{array}$ & $\begin{array}{r}\mathrm{I} 25740 \\
\mathrm{I} 4340\end{array}$ \\
\hline $\begin{array}{l}0.02 \text { M-Citrate- } \\
\text { phosphate buffer } \\
\text { pH } 2 \cdot 8^{*}\end{array}$ & $\begin{array}{l}{\left[\mathrm{I}-{ }^{14} \mathrm{C}\right] \text { acetate }} \\
{\left[\mathrm{I}^{14} \mathrm{C}\right] \text { acetate }+} \\
\text { Io mM-EDTA } \\
{\left[2-^{14} \mathrm{C}\right] \text { malonate }} \\
{\left[2^{14} \mathrm{C}\right] \text { malonate }+} \\
10 \mathrm{mM} \text {-EDTA }\end{array}$ & $\begin{array}{l}138240 \\
227620\end{array}$ & $\begin{array}{l}433000 \\
651040\end{array}$ & $\begin{array}{l}356320 \\
430380\end{array}$ & $\begin{array}{l}10460 \\
14840 \\
\\
4840 \\
7820\end{array}$ & $\begin{array}{l}107680 \\
144840 \\
38360 \\
74960\end{array}$ \\
\hline $\begin{array}{l}0.02 \mathrm{M}-\text { Citrate- } \\
\text { phosphate buffer } \\
\text { pH } 2 \cdot 8 \dagger\end{array}$ & $\begin{array}{l}{\left[\mathrm{I}-{ }^{14} \mathrm{C}\right] \text { acetate }} \\
{\left[\mathrm{I}-{ }^{14} \mathrm{C}\right] \text { acetate }+ \text { avidin }} \\
(0.5 \mathrm{mg} / \mathrm{ml}) \\
{\left[2-{ }^{14} \mathrm{C}\right] \mathrm{malonate}} \\
{\left[2-{ }^{14} \mathrm{C}\right] \mathrm{malonate}+} \\
\text { avidin }(0.5 \mathrm{mg} / \mathrm{ml})\end{array}$ & $\begin{array}{l}30610 \\
31200\end{array}$ & $\begin{array}{l}\text { I } 25080 \\
\text { I } 26960\end{array}$ & $\begin{array}{l}80740 \\
86340\end{array}$ & $\begin{array}{l}3700 \\
3360\end{array}$ & $\begin{array}{l}25840 \\
22960\end{array}$ \\
\hline
\end{tabular}

* Fifty $\mathrm{ml}$ resuspension medium containing $50 \mu \mathrm{Ci}$ of labelled compound were used.

$\dagger$ Ten $\mathrm{ml}$ resuspension medium containing I $\mu \mathrm{Ci}$ of labelled compound were used.

Table 3. Incorporation of $\left[\mathrm{I}^{-14} \mathrm{C}\right]$ acetate and $\left[2-{ }^{14} \mathrm{C}\right]$ malonate into mycelial fractions

\section{Fractions analysed}

Radioactivity remaining in resuspension buffer

$\mathrm{CHCl}_{3}$ extract of mycelium

$\mathrm{CHCl}_{3}: \mathrm{MeOH}(2: \mathrm{I}, \mathrm{v} / \mathrm{v})$ extract of mycelium

Residual mycelium

$\mathrm{CO}_{2}$ evolved

Aflatoxins in the $\mathrm{CHCl}_{3}$ extract

\begin{tabular}{|c|c|}
\hline \multicolumn{2}{|c|}{$\begin{array}{l}\text { Percentage distribution of } \\
\text { radioactivity from }\end{array}$} \\
\hline$\left[\mathrm{I}^{-14} \mathrm{C}\right]$ acetate & {$\left[2-{ }^{14} \mathrm{C}\right]$ malonate } \\
\hline $38 \cdot 8$ & $88 \cdot 4$ \\
\hline $8 \cdot 6$ & 3.4 \\
\hline $32 \cdot 8$ & $3 \cdot 6$ \\
\hline $7 \cdot 2$ & 0.7 \\
\hline $3 \cdot 0$ & 0.5 \\
\hline$I \cdot O$ & 0.5 \\
\hline
\end{tabular}

EDTA to increase membrane permeability (Sriprakash \& Ramakrishnan, 1970). EDTA increased the incorporation of both acetate and malonate, the effect being more pronounced in the case of malonate (Table I). With EDTA (IO $\mathrm{mM}$ ) in citrate-phosphate buffer $\mathrm{pH} 2 \cdot 8$, the incorporation observed with malonate was about $50 \%$ of that obtained with acetate. Lowering the $\mathrm{pH}$ to $2 \cdot 0$ did not increase incorporation.

To determine whether malonate was directly incorporated into aflatoxins or metabolized to acetate before incorporation, large quantities of unlabelled acetate were added to the phosphate buffer. With $40 \mathrm{mg}$ of unlabelled acetate, the specific activities of aflatoxins with $\left[\mathrm{I}^{14} \mathrm{C}\right]$ acetate and $\left[{ }^{2-14} \mathrm{C}\right]$ malonate were reduced by 75 and $25 \%$ respectively (Table I), which suggests that malonate was directly incorporated into aflatoxins. Addition of $200 \mathrm{mg}$ unlabelled acetate resulted in visible damage to the mycelium within $2 \mathrm{~h}$ and the release of all the radioactivity that was taken up in earlier periods of incubation. The decreased incorporation of malonate and acetate observed in the presence of $40 \mathrm{mg}$ of unlabelled acetate could have been due to some incipient damage to the mycelium.

If malonate was an intermediate in the biosynthesis of aflatoxins, an inhibitor of acetylCoA carboxylase could be expected to reduce acetate incorporation. However, addition of 
avidin $(0.5 \mathrm{mg} / \mathrm{ml})$ to the citrate-phosphate buffer $\mathrm{pH} 2.8$ did not affect the incorporation of either $\left[\mathrm{I}^{14} \mathrm{C}\right]$ acetate or $\left[2-{ }^{14} \mathrm{C}\right]$ malonate into aflatoxins, free fatty acids or triglycerides to any large extent (Table 2). Probably the mycelium is not permeable to avidin.

The effects of $\mathrm{pH}$ and of EDTA on the incorporation of acetate and malonate into aflatoxins and into sterols, triglycerides and free fatty acids were compared. The patterns obtained under different conditions were nearly the same for aflatoxins, triglycerides, free fatty acids and free and esterified sterols (Table 2), which suggests that malonate is incorporated directly not only into free fatty acids and triglycerides but also into aflatoxins and sterols.

From a study of the uptake and distribution of $\left[\mathrm{I}^{-14} \mathrm{C}\right]$ acetate and $\left[2-{ }^{14} \mathrm{C}\right]$ malonate in different mycelial fractions (Table 3 ) it was possible to account for 90.4 and $96.6 \%$, respectively of the added labelled compound. Of this, $6 \mathrm{I} \cdot 2 \%$ of the labelled acetate was taken up by the mycelium, but only I I $6 \%$ of the added malonate. However, I \% of the added acetate and $0.5 \%$ of the added malonate were incorporated into aflatoxins. Label, evolved as $\mathrm{CO}_{2}$, accounted for only about 3.0 and $0.5 \%$ of $\left[\mathrm{I}^{14} \mathrm{C}\right]$ acetate and $\left[2{ }^{14} \mathrm{C}\right]$ malonate, respectively. This means that $4.3 \%$ of the malonate entering the mycelium was incorporated into aflatoxins compared with about $\mathrm{I} \cdot 6 \%$ of the acetate. These results suggest that malonate is an intermediate in aflatoxin synthesis and there is a strong possibility that it is incorporated into aflatoxins without prior conversion to acetate.

This work was supported in part by a PL-480 grant No. FG-In-438.

\section{REFERENCES}

AdyE, J. C. \& MATELES, R. I. (1964). Incorporation of labelled compounds into aflatoxins. Biochimica et biophysica acta 86, $4 \mathrm{I} 8-420$.

Bentley, R. \& KeIL, J. G. (I961). The role of acetate and malonate in the biosynthesis of penicillic acid. Proceedings of the Chemical Society, I I I-I I 2.

Biollaz, M., BüchI, G. \& Milne, G. (I968). The biosynthesis of aflatoxins. Journal of the American Chemical Society 90, 5017-5020.

Biollaz, M., Büchi, G. \& Milne, G. (1970). The biosynthesis of aflatoxins. Journal of the American Chemical Society 92, I035-1043.

Birch, A. J., Cassera, A. \& Rickards, R. W. (I961). Intermediates in biosynthesis from acetate units. Chemistry and Industry, 792-793.

Bu'Lock, J. D. \& SMalley, H. M. (1961). Biosynthesis of aromatic substances from acetyl- and malonylcoenzyme A. Proceedings of the Chemical Society, 209-21 I.

Detroy, R. W. \& Hesseltine, C. W. (1969). Net synthesis of ${ }^{14}$ C-labelled lipids and aflatoxins in resting cells of Aspergillus parasiticus. Developments in Industrial Microbiology 10, I 27-I 33.

Gupta, S. R., Prasanna, H. R., Viswanathan, L. \& Venkitasubramanian, T. A. (I974). Production of aflatoxins, and acetate $\left[\mathrm{I}^{14} \mathrm{C}\right]$ incorporation, by Aspergillus parasiticus. Journal of General Microbiology $80,31-36$.

Hsien, D. P. H. \& Mateles, R. I. (1970). The relative contribution of acetate and glucose to aflatoxin biosynthesis. Biochimica et biophysica acta 208, 482-486.

Hsieh, D. P. H. \& Mateles, R. I. (1971). Preparation of labelled aflatoxins with high specific activities. Applied Microbiology 22, 79-83.

Lin, M. T., Hsieh, D. P. H., Yao, R. C. \& Donkersloot, J. A. (1973). Conversion of averufin into aflatoxins by Aspergillus parasiticus. Biochemistry 12, 5167-5I7I.

MisRA, U. K. (I968). Thin layer chromatographic estimation of rat plasma and tissue lipids. Biochimia et biologia sperimentale 7, 57-60.

Nabney, J. \& Nesbitt, B. F. (1965). A spectrophotometric method for determining the aflatoxins. Analyst 90, I55-160.

SRIPRAKaSh, K. S. \& RAMAKRISHNAN, T. (1970). Isoniazid-resistant mutants of Mycobacterium tuberculosis H37RV: uptake of isoniazid and the properties of NADase inhibitor. Journal of General Microbiology 6o, I $25-132$.

WebB, J. L. (1966). Enzyme and Metabolic Inhibitors, vol. 2, p. I86. New York: Academic Press. 